\title{
Investigation of Short and Long-Term Complications of Respiratory System After Esophageal Atresia and/or Tracheoesophageal Fistular Surgery
}

\author{
Özofagus Atrezisi ve/veya Trakeoözofageal Fistül \\ Cerrahisi Sonrası Solunum Sistemi Erken ve Geç \\ Dönem Komplikasyonlarının incelenmesi
}

\begin{abstract}
Objective: Esophageal atresia (EA) and/or tracheoesophageal fistula (TEF) is one of the common developmental anomalies of the foregut. Despite advances in surgical techniques and postoperative care, respiratory system complications affect the quality of life of patients. We planned to evaluate our patients in terms of the general features, the risk factors for respiratory morbidity and short- and long-term respiratory complications after corrective surgical treatment.

Method: Thirty-six patients with the diagnosis of EA and/or TEF and followed after surgical treatment between 2002 and 2019 were retrospectively enrolled in the study.

Results: The most common symptom was chronic cough (77.7\%) and wheezing (41.6\%). Recurrent pulmonary infections were present in the great majority of the patients. The frequency of pulmonary infections was higher in patients who had undergone dilatation due to stricture $(N=14)$ and in patients with recurrent $\operatorname{TEF}(N=6)$ and malacia $(N=10)$. Bronchiectasis was present in eight patients and hospital admission due to infections was highly frequent. Aeroallergen sensitivity was detected in four and food allergy in five patients. Scoliosis was present in $33.3 \%$ of the patients all of whom had recurrent pulmonary infections. Pulmonary function tests were performed in 10 patients. Five patients had impaired pulmonary function. Medical treatment for reflux was given to the majority of patients $(N=30)$, while fundoplication was performed in 10 patients. Most of the patients had a significant decrease in the frequency of pulmonary infections after the procedure.

Conclusion: The etiology of pulmonary complications is multifactorial and many factors affect each other. Evaluation and management of the patients for each complication will improve the quality of life and comfort of the patients.
\end{abstract}

Keywords: Esophageal atresia, tracheoesophageal fistula, respiratory system complications

öz

Amaç: Özofagus atrezisi (ÖA) ve/veya trakeoözofageal fistül (TÖF) önbağırsağın en sık gelişsim anomalilerinden biridir. Cerrahi teknikler ve operasyon sonrası bakımdaki ilerlemelere rağmen, solunum sistemi komplikasyonları hastaların yaşam kalitesini etkilemektedir. Bu nedenle çalışmamızda, hastaların genel özelliklerini, respiratuvar morbidite risk faktörlerini ve düzeltme operasyonu sonrası solunum sistemi erken ve geç dönem komplikasyonlarını değerlendirmeyi amaçladık.

Yöntem: Calısmaya 2002-2019 yılları arasında ÖA ve/veya TÖF tanısı ile düzeltme operasyonu sonrası takip edilen 36 hasta dahil edildi.

Bulgular: En sık semptom kronik öksürük $(\% 77,7)$ ve hışıltı $(\% 41,6)$ idi. Hastaların büyük çoğunluğunda yineleyen akciğer enfeksiyonu vardı. Akciğer enfeksiyonu sıklığı striktür nedeniyle dilatasyon uygulanan $(N=14)$, rekürren TÖF $(N=6)$ saptanan ve malazi $(N=10)$ bulunan hastalarda daha fazlaydı. Bronşektazi sekiz hastada vardı ve bu hastalarda akciğer enfeksiyonu nedeniyle hastaneye bașvuru sıktı. Dört hastada aeroallerjen duyarlılığı ve beş hastada besin alerjisi saptanmıştı. Skolyoz hastaların \%33,3'ünde vardı ve bu hastaların hepsinde yineleyen akciğer enfeksiyonu bulunmaktaydı. Solunum fonksiyon testi 10 hastaya uygulanmıştı. Beş hastada solunum fonksiyon testinde düşüklük vardı. Hastaların büyük çoğunluğuna $(N=30)$ reflü nedeniyle medikal tedavi başlanmıştı. On hastaya fundoplikasyon işlemi uygulanmıştı. İ̧̧lem sonrası birç̧ok hastada akciğer enfeksiyonu sıklığında belirgin azalma gözlenmişti.

Sonuç: Hastalarda pulmoner komplikasyonların etiyolojisi multifaktöriyeldir ve birçok faktör birbirini etkilemektedir. Hastaların komplikasyonlar açısından değerlendirilmesi ve yönetimi, yaşam kalitesi ve konforunu arttıracaktır.

Anahtar kelimeler: Özofagus atrezisi, trakeoözofageal fistül, solunum sistemi komplikasyonları
Received/Geliş: 03.12.2019

Accepted/Kabul: 10.05 .2020

Published Online: 22.12 .2020

Gökçen Kartal Öztürk Ege Üniversitesi Tıp Fakültesi, Çocuk Sağlığı ve Hastalıkları Anabilim Dalı, Çocuk Göğüs Hastalıkları Bilim Dalı, İzmir - Türkiye

gokcen_kartal@hotmail.com ORCID: 0000-0002-0793-9710

A. Eşki 0000-0001-5378-5663

E. Demir 0000-0003-2736-8924

F. Gülen 0000-0002-5431-3913

Ege Üniversitesi Tıp Fakültesi, Çocuk Sağlığı ve Hastalıkları Anabilim Dalı, Çocuk Göğüs Hastalıkları Bilim Dalı, izmir, Türkiye 
G. K. Öztürk ve ark., Investigation of Short and Long-Term Complications of Respiratory System After Esophageal Atresia and/or Tracheoesophageal Fistular Surgery

\section{INTRODUCTION}

Esophageal atresia (EA) with or without tracheoesophageal fistula (TEF) is one of the common developmental anomalies of the foregut. The frequency of EA is one in 2500-4500 live births and it is more common in males. While EA may be a component of a syndrome, another anomalies might also accompany in approximately $50 \%$ of the cases ${ }^{(1,2)}$. Although antenatal diagnosis can be made, the clinical features vary according to the type of the anomaly. However, it is often diagnosed with symptoms such as increased salivation, failure of the nasogastric tube to reach the stomach, and feeding problems, and then surgical treatments are performed as soon as possible.

The problems related to the respiratory system are common at every stage of the disease. Inability to clear respiratory secretions due to tracheomalacia and swallowing disorders, esophageal dysmotility, stricture and gastroesophageal reflux (GER) and recurrent TEF have been implicated in the etiology of respiratory system problems ${ }^{(3-8)}$. Complications such as wheezing, recurrent bronchitis, and pneumonia are common in the early years, their frequency decreases over time. Impaired pulmonary function is one of the common long-term complications. Despite advances in surgical techniques and postoperative care; respiratory system complications affect the quality of life of patients in childhood and adulthood. Management of short- and long-term postoperative complications is important.

Our unit is a reference center for pediatric pulmonary diseases. EA and/or TEF patients have been followed for pulmonary complications after surgical repair and management of these complications for a long time. Therefore, we planned to evaluate our patients in terms of general features, the risk factors for respiratory morbidity and short- and long-term respiratory complications developing after surgical treatment.

\section{MATERIAL and METHODS}

Patients with EA and/or TEF and followed after surgical treatment in our department between 2002 and 2019 were retrospectively enrolled in the study. The study was approved by the Clinical Research Ethics Committee of our university (19-10T/33).

Demographic characteristics (1) of the patients, (2) type of anomaly, (3) additional anomalies (VACTERL, CHARGE syndrome, Feingold syndrome, cardiovascular anomalies, neuromuscular, respiratory and gastrointestinal system anomalies, etc.), (4) respiratory system characteristics (symptoms, history of pulmonary infections and bronchiolitis in the first year of life, recurrent pulmonary infection, atopy, bronchial hyperreactivity, scoliosis, etc.), (5) gastrointestinal system characteristics (symptoms, reflux treatment, etc.), (6) radiographic results for a barium swallow, (7) chest computed tomography (CT), (8) bronchoscopy, (9) pulmonary function tests (PFT) (forced vital capacity (FVC), forced expiratory volume in 1 second (FEV1), FEV1 / FVC ratio, forced mid expiratory flow rate (FEF25-75)) were evaluated.

\section{Statistical Analysis}

Statistical analysis was performed using Statistical Package for the Social Sciences Statistics Package V.20.0. Shapiro-Wilk test was used to test the normality of data distribution. Continuous variables are presented as mean \pm SD and median $\left(25^{\text {th }}\right.$ and $75^{\text {th }}$ percentile). Categorical variables are presented as percentages. Mann-Whitney test was used to compare continuous variables between groups. Statistical significance was accepted as $p<0.05$.

\section{RESULTS}

Thirty-six patients were included in the study. The mean age of the study population was 102.6 \pm 54.9 months. The male to female ratio was equal. Twentyeight patients $(77.8 \%)$ had EA with distal TEF. The median age at diagnosis was 11.5 days (maximum 180 days). Most patients ( $\mathrm{N}=30)$ underwent surgical treatment within the first week of life. Demographic characteristics of the patients are shown in Table 1.

History of premature birth was present in 13 (36.1\%) patients. Mean birth weight was $2440 \pm 620$ 
grams. Low birth weight was present in $41.9 \%$ of the patients. Of the patients, $59.5 \%$ had additional anomalies, including anomalies related to cardiovascular system $(13.5 \%)$, genetic $(11 \%)$, respiratory $(5 \%)$, and neuromuscular system (5\%), and extremities (5\%).

One patient underwent bone marrow transplantation due to Fanconi aplastic anemia.

Table 1. Demographic characteristics of patients with repaired congenital esophageal atresia and/or tracheoesophageal fistula.

\begin{tabular}{|c|c|c|}
\hline $\mathrm{N}=36$ & $\mathbf{N}(\%)$ & $\begin{array}{c}\text { Mean } \pm \\
\text { Standard } \\
\text { Deviation }\end{array}$ \\
\hline Age/Month & & $102.6 \pm 54.9$ \\
\hline Gender (F/M) & $18 / 18$ & \\
\hline \multicolumn{3}{|l|}{ Maturity } \\
\hline Premature & $13(36.1)$ & \\
\hline Mature & 23 (63.9) & \\
\hline Birth weight, grams & & $2440 \pm 620$ \\
\hline Age at diagnosis, days & & $11.5(0-180)^{*}$ \\
\hline \multicolumn{3}{|l|}{ Anomaly type } \\
\hline Type A, isolated EA & 3 & \\
\hline Type B, EA with proximal TEF & 2 & \\
\hline Type C, EA with distal TEF & $28(77.8)$ & \\
\hline Type D, EA with proximal and distal TEF & 2 & \\
\hline Type $E$, isolated TEF (H Type fistula) & 1 & \\
\hline Type F, congenital esophageal stenosis & 0 & \\
\hline \multicolumn{3}{|l|}{ Surgery treatment, days } \\
\hline $0-7$ days & $30(83.3)$ & \\
\hline$>7$ days & 6 & \\
\hline \multicolumn{3}{|l|}{ Additional anomaly } \\
\hline No & $15(40.5)$ & \\
\hline VACTERL spectrum & 2 & \\
\hline CHARGE syndrome & 1 & \\
\hline Feingold syndrome & 1 & \\
\hline Cardiovascular anomalies & $5(13.5)$ & \\
\hline Respiratory system anomalies & 2 & \\
\hline Neuromuscular anomalies & 2 & \\
\hline Extremity anomalies & 2 & \\
\hline Others & $6(16.6)$ & \\
\hline
\end{tabular}

F: female, M: male. *Median (minimum-maximum).

\section{Respiratory system}

The most common respiratory symptoms are chronic cough $(77.7 \%)$, wheezing $(41.6 \%)$, and stridor $(27.7 \%)$. Recurrent pulmonary infections and wheezing were present in the majority of patients $(\mathrm{N}=34)$.

Bronchoscopy was performed in 14 patients. Malacia (tracheomalacia and bronchomalacia) were detected in 10 patients. Four patients underwent tracheostomy for severe malacia and tracheal steno- sis. Recurrent TEF was observed in six patients (16.6\%). Chest computed tomography was performed in 29 patients due to current respiratory symptoms. Atelectasis $(\mathrm{N}=17)$ and mosaic oligemia $(\mathrm{N}=11)$ were the most common results. Five patients had aspiration pneumonia. Bronchiectasis was present in eight patients.

Eleven patients (30.5\%) were evaluated for atopy because of recurrent episodes of wheezing and atopic dermatitis. Aeroallergen sensitivity (house dust mites, grass, and pollen) was detected in four and food allergy (milk and egg white) in five patients.

Pulmonary function tests were performed in 10 patients. The mean values for FEV1 $(70.3 \% \pm 21.4 \%)$, FVC (63.5\% $\pm 17.6 \%)$, FEV1/FVC (107.1\% $\pm 8.5 \%)$ and FEF25-75 (68.1\% $\pm 24.8 \%)$ were estimated as indicated. Scoliosis was present in $33.3 \%$ of the patients. The respiratory system evaluation of the patients is given in Table 2.

Table 2. Evaluation of the respiratory system in patients with repaired congenital esophageal atresia and/or tracheoesophageal fistula.

\begin{tabular}{|c|c|c|}
\hline & $\mathrm{N}(\%)$ & $\begin{array}{c}\text { Mean } \pm \\
\text { Standard } \\
\text { Deviation }\end{array}$ \\
\hline Clinical characteristics & 36 & \\
\hline Wheezing & 15 & \\
\hline Chronic cough & 28 & \\
\hline Stridor & 10 & \\
\hline Recurrent pulmonary infections & 34 & \\
\hline Pulmonary function test, $\%$ & $10(27.7)$ & \\
\hline FEV1 & & $70.3 \pm 21.4$ \\
\hline FVC & & $63.5 \pm 17.6$ \\
\hline FEV1/FVC & & $107.1 \pm 8.5$ \\
\hline FEF25-75 & & $68.1 \pm 24.8$ \\
\hline Bronchoscopy & $14(38.8)$ & \\
\hline Tracheomalacia & 8 & \\
\hline Bronchomalacia & 2 & \\
\hline Recurrent TEF & 6 & \\
\hline Tracheal stenosis & 2 & \\
\hline Computed tomography of the chest & $29(80.5)$ & \\
\hline Normal & 3 & \\
\hline Tracheomalacia and/or bronchomalacia & 9 & \\
\hline Bronchitis & 5 & \\
\hline Atelectasis & 17 & \\
\hline Aspiration pneumonia & 5 & \\
\hline Mosaic oligemia & 11 & \\
\hline Bronchiectasis & 8 & \\
\hline
\end{tabular}

FEV1: forced expiratory volume in 1 second, FEF25-75: flow rate in the middle of forced expiration, FVC: forced vital capacity. 
G. K. Öztürk ve ark., Investigation of Short and Long-Term Complications of Respiratory System After Esophageal Atresia and/or Tracheoesophageal Fistular Surgery

\section{Gastrointestinal system}

When gastrointestinal system-related problems were evaluated, vomiting (50\%) and dysphagia $(30.5 \%)$ were found to be the most common symptoms. Twenty-five of the patients underwent barium swallow. The most common findings were reflux $(n=9,36 \%)$ and reflux with stricture $(n=11$, $44 \%)$. Medical treatment for reflux was given to the majority of patients $(n=30)$, while fundoplication was performed in 10 patients. Dilatations were performed in 14 patients due to esophageal stricture.

\section{Related factors}

The number of pulmonary infections in the first year of life was found to be significantly higher in low birth weight infants $(p<0.05)$. No statistically significant difference was found between the frequency of pulmonary infection when patients with premature and mature births were compared $(p<0.05)$. The number of pulmonary infections was similar in the group with and without comorbidities ( $p>0.05)$. In patients with malacia, the incidence of pneumonia in the first year of life was significantly higher than those without $(p<0.05)$. The incidence of pulmonary infection was statistically higher in patients who underwent dilatation $(p<0.05)$. Short- and long-term complications are presented in Table 3.

Table 3. Short-term and long-term complications in patients with repaired congenital esophageal atresia and/or tracheoesophageal fistula.

\begin{tabular}{lcc}
\hline & N & $\%$ \\
\hline Short-term complications & & \\
Stricture & 14 & 38.8 \\
Recurrent TEF & 6 & 16.7 \\
Long-term complications & & \\
Malacia (tracheomalacia and/or bronchomalacia) & 10 & 27.7 \\
Vocal cord dysfunction & 2 & 5.5 \\
Bronchiectasis & 8 & 22.2 \\
Asthma/allergy & $4 / 9$ & $11 / 25$ \\
Chest wall anomalies (scoliosis) & 12 & 33.3 \\
Impaired pulmonary function & 5 & 13.8 \\
Gastroesophageal reflux & 30 & 83.3 \\
Swallowing and feeding problems & 16 & 44.4 \\
\end{tabular}

\section{Mortality}

One of the patients who underwent tracheostomy for severe tracheomalacia died due to recurrent tracheostomy-related pulmonary infection.

\section{DISCUSSION}

In our study, general features of patients, risk factors for respiratory system morbidity (ies), short-, and long-term respiratory complications were evaluated in patients who underwent surgical treatment due to EA and/or TEF.

In infants born with EA and/or TEF, premature and low birth weight were observed at a rate of 20-40\%; however, there were conflicting results between pulmonary morbidities and complications in these patients. Deurloo et al. ${ }^{(9)}$ demonstrated that low birth weight was associated with complicated clinical conditions observed in the first year of life, whereas Legrand et al. ${ }^{(10)}$ reported premature birth and intrauterine growth retardation were not associated with long-term respiratory complications and PFT impairment. In a study by Pedersen et al., comparing 59 patients aged 5-15 years with EA and/or TEF with the control group, increased gestational age and body mass index z-scores were found to be protective for pulmonary morbidity. The reason for that observation was reported to be potentially related to pulmonary complications which can be observed in premature births ${ }^{(11)}$. In our study, no statistically significant difference was found between the frequency of pulmonary infections when patients with premature and term births were compared ( $p>0.05$ ). Low birth weight was present in $41.9 \%$ of the patients. The number of pulmonary infections in the first year of life was found to be significantly higher in low birth weight infants $(p<0.05)$.

Additional anomalies may accompany $50 \%$ of EA and/or TEF patients ${ }^{(1,2)}$. Recent studies have shown that parenchymal anomalies of the lungs (such as pulmonary hypoplasia) may be a component of the VACTERL spectrum. Although concomitant anomalies are thought to affect pulmonary morbidity, studies investigating long-term complications reported no predictive role for anomalies in the deterioration of PFT ${ }^{(12,13)}$. There was no statistically significant difference between the groups with and without additional anomalies as for the number of pulmonary infections ( $p>0.05)$.

One of the causes of early recurrent pulmonary 
infections and aspiration pneumonia is the development of stricture in the anastomosis line. Recurrent esophageal dilatations are performed during the course of the treatment ${ }^{(14)}$. Different rates of anastomotic strictures have also been demonstrated by Celayir ${ }^{(15)}$, Bakal ${ }^{(16)}$ and Taşkınlar ${ }^{(17)}$ in $7.4 \%, 20 \%$, $55 \%$ of their patients, respectively. In our study, $38.8 \%$ of the patients had esophageal stricture on barium swallow and 14 patients had dilatation due to the presence of a stricture. The number of pulmonary infections were statistically higher in patients who underwent dilatation ( $p>0.05$ ).

Recurrent TEF may be seen in $5-10 \%$ of patients in the early postoperative period ${ }^{(18)}$. In a study, 43 patients aged between 3 and 20 years who underwent repair EA and/or TEF were retrospectively evaluated. Recurrent TEF was observed in barium swallow in $15.4 \%$ of the patients, while recurrent TEF was detected in $20 \%$ of the patients by bronchoscopy and esophagoscopy. Recurrent pulmonary infections were observed in all patients with recurrent fistulas $(\mathrm{N}=6)$. Therefore, endoscopic evaluation is recommended in patients with esophageal symptoms. Since pulmonary morbidity is increased in these patients, it is recommended to evaluate the patients with PFT annually ${ }^{(19)}$. In our study, $16.7 \%(\mathrm{~N}=6)$ of the patients had recurrent TEF following esophagoscopic and bronchoscopic examinations. In our study all patients with fistula had chronic cough symptoms and recurrent pulmonary infections. Patients with recurrent fistulas underwent surgical treatment.

The factors affecting long-term pulmonary complications and pulmonary morbidity can be classified as factors related to upper and lower airways, gastrointestinal tract, aspiration and dysphagia (8). Tracheomalacia is the most common factor affecting upper airways and can be observed in $37-75 \%$ of patients ${ }^{(20)}$. In our study, 10 patients $(27.7 \%)$ had malacia. Malacia was found in 9 patients who underwent bronchoscopy and 9 patients who underwent chest CT. Two patients underwent aortopexy and four patients tracheostomy for severe malacia and tracheal stenosis. Tracheomalacia can cause recurrent pulmonary infections by disrupting clearance of secretions. In patients with malacia, the incidence of pneumonia in the first year of life was significantly higher than those without $(p<0.05)$. Less frequent complications of other upper airways are the presence of laryngeal cleft and vocal cord dysfunction. In our study, laryngeal cleft was detected in one and vocal cord dysfunction in two patients.

One of the long-term complications is impaired pulmonary function tests. More frequently restrictive type, less frequently obstructive type, and both restrictive and obstructive type disorders can be seen. The cause of deterioration in pulmonary function has not been fully explained. Sistonen et al. performed an adult study in patients who underwent corrective surgery EA and/or TEF to investigate respiratory complications and PFTs. Multivariate logistic regression analysis revealed the presence of rib fusion due to thoracotomy detected in $1 / 3$ of the patients and the presence of GER-associated esophageal metaplasia to be the most significant risk factors for restrictive type ventilation defects. There was no correlation with age, presence of tracheomalacia, history of pneumonia, airway inflammation and respiratory symptoms in childhood $(p>0.05)^{(12)}$. Chest wall anomalies and scoliosis are also common. These problems may pave the way for the development of restrictive type ventilation defects ${ }^{(21)}$. In our study, pulmonary function test was performed in 10 patients. The mean values for FEV1 (70.3\% $21.4 \%)$, FVC $(63.5 \% \pm 17.6 \%)$ and MEF25-75 (68.1\% $\pm 24.8 \%)$ were also estimated. The patients were not classified as restrictive, obstructive or mixed type because of the small number of patients who underwent pulmonary function tests and isolated spirometry measurements. Five patients had impaired pulmonary function. Scoliosis was present in $33.3 \%$ of the patients all of whom had recurrent pulmonary infections.

The incidence of physician-diagnosed asthma is higher in patients with EA and/or TEF. The frequency increases, especially in older children. In a study, recurrent wheezing episodes were found in $22 \%$ of the patients who underwent surgical treatment for EA and/or TEF, and $22 \%$ of the patients were diagnosed with asthma ${ }^{(3)}$. In another study, when the patients were compared with the control 
G. K. Öztürk ve ark., Investigation of Short and Long-Term Complications of Respiratory System After Esophageal Atresia and/or Tracheoesophageal Fistular Surgery

group, the frequency of physician-diagnosed asthma was found to be $16 \%$ in EA and/or TEF patients, and $6 \%$ in the control group. In the same study, allergy was detected in $42 \%$ of the patients. Multiple aeroallergen sensitivity has been reported to be associated with respiratory symptoms, and high immunoglobulin E levels with bronchial hyperreactivity ${ }^{(12)}$. In our study, aeroallergen sensitivity was detected in 4 of 11 patients with recurrent wheezing and food allergy in 5 patients. All patients with aeroallergen sensitivity had used inhaled bronchodilators and inhaled steroids.

Several patients with gastrointestinal system problems require medical treatment due to reflux. Fundoplication is performed in patients with nutritional problems and recurrent pulmonary infections unresponsive to medical treatment. The frequency of fundoplication varies between $25-72 \%$ according to the health centers. There is no conclusive evidence of the effect of fundoplication on pulmonary function ${ }^{(11)}$. In our study, fundoplication was performed in 10 patients (27.7\%). Most of the patients had a significant decrease in the frequency of pulmonary infections and bronchiolitis/bronchitis after the procedure.

The limitations of our study included the lack of evaluation of complications such as surgical procedures, duration of mechanical ventilation, intensive care unit follow-up time, early postoperative anastomotic leakage, pneumothorax, and sepsis. Since our unit is the reference center for pediatric pulmonary diseases where patients with increased risk for pulmonary complications are monitored, the number of patients with respiratory system problems is high in our study.

Respiratory morbidity is a common complication after surgical treatment in patients with EA and/or TEF. Although its frequency decreases with age, the quality of life is affected. Since the etiology is multifactorial and many factors affect each other, the management of these patients in multidisciplinary centers is important. Evaluation and management of the patients for each complication will improve the quality of life and comfort of the patients.

\section{Acknowledgments}

Financial/nonfinancial disclosures: The authors have reported to The Journal of Dr. Behçet Uz Children's Hospital that no potential conflicts of interest exist with any companies/organizations whose products or services may be discussed in this article.

Role of sponsors: This study has no sponsors.

Other contributions: The authors thank the patients, and laboratory staff members Gökay Çelik for spirometry and Sinem Özen for allergen skin prick tests.

Ethics Committee Approval: T.C. Ege University Rectorate Medical Faculty Dean's Office Medical Research Ethics Committee approval was obtained (10.04.2016/19-10T/33).

Conflict of Interest: None.

Funding: None.

Informed Consent: Written consent was obtained from parents

\section{REFERENCES}

1. Sfeir R, Michaud L, Salleron J, Gottrand F. Epidemiology of esophageal atresia. Diseases of the esophagus: official journal of the International Society for Diseases of the Esophagus. 2013;26(4):354-5.

https://doi.org/10.1111/dote.12051

2. Pini Prato A, Carlucci M, Bagolan P, Gamba PG, Bernardi M, Leva $E$, et al. A cross-sectional nationwide survey on esophageal atresia and tracheoesophageal fistula. Journal of pediatric surgery. 2015;50(9):1441-56. https://doi.org/10.1016/j.jpedsurg.2015.01.004

3. Malmstrom K, Lohi J, Lindahl H, Pelkonen A, Kajosaari M, Sarna S, et al. Longitudinal follow-up of bronchial inflammation, respiratory symptoms, and pulmonary function in adolescents after repair of esophageal atresia with tracheoesophageal fistula. The Journal of pediatrics. 2008;153(3):396401.

https://doi.org/10.1016/j.jpeds.2008.03.034

4. Castilloux J, Noble AJ, Faure C. Risk factors for short- and long-term morbidity in children with esophageal atresia. The Journal of pediatrics. 2010;156(5):755-60. https://doi.org/10.1016/j.jpeds.2009.11.038

5. Kovesi T. Long-term respiratory complications of congenital esophageal atresia with or without tracheoesophageal fistula: an update. Diseases of the esophagus: official journal of the International Society for Diseases of the Esophagus. 2013;26(4):413-6. https://doi.org/10.1111/dote.12061

6. Fragoso AC, Tovar JA. The multifactorial origin of respiratory morbidity in patients surviving neonatal repair of esophageal atresia. Frontiers in pediatrics. 2014;2:39. https://doi.org/10.3389/fped.2014.00039 
7. Sadreameli SC, McGrath-Morrow SA. Respiratory Care of Infants and Children with Congenital Tracheo-Oesophageal Fistula and Oesophageal Atresia. Paediatric respiratory reviews. 2016;17:16-23.

https://doi.org/10.1016/j.prrv.2015.02.005

8. Patria MF, Ghislanzoni S, Macchini F, Lelii M, Mori A, Leva E, et al. Respiratory morbidity in children with repaired congenital esophageal atresia with or without tracheoesophageal fistula. International Journal of Environmental Research and Public Health. 2017;14(10):1136. https://doi.org/10.3390/ijerph14101136

9. Deurloo JA, Smit BJ, Ekkelkamp S, Aronson DC. Oesophageal atresia in premature infants: an analysis of morbidity and mortality over a period of 20 years. Acta paediatrica (Oslo, Norway: 1992). 2004;93(3):394-9. https://doi.org/10.1111/j.1651-2227.2004.tb02968.x

10. Legrand C, Michaud L, Salleron J, Neut D, Sfeir R, Thumerelle $C$, et al. Long-term outcome of children with oesophageal atresia type III. Archives of disease in childhood. 2012;97(9):808-11. https://doi.org/10.1136/archdischild-2012-301730

11. Pedersen RN, Markow S, Kruse-Andersen S, Qvist N, Gerke O, Husby $S$, et al. Long-term pulmonary function in esophageal atresia-A case-control study. Pediatric pulmonology. 2017;52(1):98-106. https://doi.org/10.1002/ppul.23477

12. Sistonen S, Malmberg P, Malmstrom K, Haahtela T, Sarna S, Rintala RJ, et al. Repaired oesophageal atresia: respiratory morbidity and pulmonary function in adults. The European respiratory journal. 2010;36(5):1106-12. https://doi.org/10.1183/09031936.00153209

13. Parelkar SV, Sanghvi BV, Vageriya NL, Samala DS, Paradkar BA, Oak SN. Unilateral lung agenesis associated with esophageal atresia \& tracheoesophageal fistula: Report of two cases \& review of literature. J Pediatr Surg Case Rep. 2014;1:203-6. https://doi.org/10.1016/j.epsc.2013.06.003

14. Parolini F, Leva E, Morandi A, Macchini F, Gentilino V, Di
Cesare A, et al. Anastomotic strictures and endoscopic dilatations following esophageal atresia repair. Pediatric surgery international. 2013;29(6):601-5. https://doi.org/10.1007/s00383-013-3298-4

15. Celayir S, Iliçe Z, Tekand GT, et al. The experience with esophagus atresia (1978-2000). Cerrahpaşa J Med. 2002;33:86-92.

16. Bakal U, Ersoz F, Eker I, Sarac M, Aydin M, Kazez A. Long-term prognosis of patients with esophageal atresia and/or tracheoesophageal fistula. Indian J Pediatr. 2016;83(5):401-4. https://doi.org/10.1007/s12098-015-1930-0

17. Taskınlar H, Kıllı Y, Çelik Y, Avlan D, Naycı A. Experiences in patients with esophageal atresia and tracheoesophageal fistula. Journal of the Turkish Association of Pediatric Surgeons and The Society for Pediatric Urology in Turkey. 2012;26(2):32-6.

https://doi.org/10.5222/JTAPS.2012.032

18. Smithers CJ, Hamilton TE, Manfredi MA, Rhein L, Ngo P, Gallagher D, et al. Categorization and repair of recurrent and acquired tracheoesophageal fistulae occurring after esophageal atresia repair. Journal of pediatric surgery. 2017;52(3):424-30.

https://doi.org/10.1016/j.jpedsurg.2016.08.012

19. Cartabuke RH, Lopez R, Thota PN. Long-term esophageal and respiratory outcomes in children with esophageal atresia and tracheoesophageal fistula. Gastroenterology report. 2016;4(4):310-4. https://doi.org/10.1093/gastro/gov055

20. Hseu A, Recko T, Jennings R, Nuss R. Upper airway anomalies in congenital tracheoesophageal fistula and esophageal atresia patients. The Annals of Otology, Rhinology, and Laryngology. 2015;124(10):808-13. https://doi.org/10.1177/0003489415586844

21. Mirra V, Maglione M, Di Micco LL, Montella S, Santamaria F. Longitudinal follow-up of chronic pulmonary manifestations in esophageal atresia: A clinical algorithm and review of the literature. Pediatrics and Neonatology. 2017;58(1):8-15. https://doi.org/10.1016/j.pedneo.2016.03.005 